\title{
ANALISIS KEMAMPUAN PENALARAN MATEMATIS PESERTA DIDIK DALAM MENYELESAIKAN SOAL CERITA DI SMAN 6 MALANG
}

\author{
Delima Mei Linola ${ }^{1}$, Retno Marsitin ${ }^{2}$, Tri Candra Wulandari ${ }^{3}$ \\ ${ }^{1}$ Program Studi Pendidikan Matematika, Universitas Kanjuruhan Malang \\ dmlinola@gmail.com \\ ${ }^{2}$ Program Studi Pendidikan Matematika, Universitas Kanjuruhan Malang \\ mars_retno@unikama.ac.id \\ ${ }^{3}$ Program Studi Pendidikan Matematika, Universitas Kanjuruhan Malang \\ fikri.chan@unikama.ac.id
}

\begin{abstract}
Abstrak: Penelitian ini merupakan penelitian kualitatif dengan jenis penelitian deskriptif kualitatif yang bertujuan untuk mendeskripsikan kemampuan penalaran matematis peserta didik dalam menyelesaikan soal cerita di SMAN 6 Malang. Subjek dalam penelitian ini adalah peserta didik kelas XI MIPA 4. Indikator yang digunakan untuk menganalisis kemampuan penalaran peserta didik antara lain (1 ) melakukan manipulasi matematika, (2) menyusun bukti dan memberikan alasan terhadap kebenara solusi, (3) menyajikan pernyataan matematika secara tertulis, diagram, dan gambar, dan (4) menarik kesimpulan pernyataan secara logis. Teknik pengumpulan data terdiri dari tes tertulis dan wawancara. Analisis data yang digunakan dalam penelitian ini meliputi reduksi data, penyajian data, dan penarikan kesimpulan. Berdasarkan analisis data diperoleh hasil bahwa kemampuan penalaran matematis peserta didik kelas XI MIPA 4 SMAN 6 Malang dalam menyelesaikan soal cerita tergolong tinggi. Peserta didik dengan kemampuan penalaran kategori rendah sebanyak $4 \%$, peserta didik dengan kemampuan penalaran kategori sedang sebanyak 32\%, dan peserta didik dengan kemampuan penalaran kategori tinggi sebanyak $64 \%$

Kata Kunci: Penalaran, Soal Cerita
\end{abstract}

\section{Pendahuluan}

Matematika sebagai ilmu dasar memegang peranan penting dalam kehidupan manusia. Hal itu sesuai dengan pendapat Hudojo (dalam Maimunah, 2016:17) yang menyatakan bahwa matematika adalah suatu alat untuk mengembangkan cara berpikir, karena sangat diperlukan dalam kehidupan sehari-hari maupun dalam menghadapi kemajuan IPTEK. Menurut Soedjadi (dalam Afif, 2016:2), matematika merupakan suatu ilmu yang didasarkan atas akal (rasio) yang berhubungan benda-benda dalam pikiran yang abstrak atau matematika memiliki objek kajian yang abstrak. Menurut Suherman (dalam Afif, 2016:3) matematika merupakan ilmu dasar yang terus mengalami perkembangan karena proses berpikir. BSNP (dalam Afif, 2016:3) menyatakan bahwa mata pelajaran matematika perlu diberikan kepada semua peserta didik mulai sekolah dasar untuk membekali peserta didik dengan kemampuan berpikir logis, analitis, sistematis, kritis, dan kreatif, serta kemampuan bekerjasama.

Memahami tujuan mempelajari matematika menurut Kemendikbud (dalam Wardhani, 2008:8), agar peserta didik memiliki kemampuan sebagai berikut:

1) Memahami konsep matematika, menjelaskan keterkaitan antar konsep dan mengaplikasikannya dalam pemecahan masalah

2) Menggunakan penalaran pada pola dan sifat, melakukan 
manipulasimatematika dalam membuat generalisasi, menyusun bukti, ataumenjelaskan gagasan dan pernyataan matematika

3) Memecahkan masalah yang meliputi kemampuan memahami masalah, merancang model matematika, menyelesaikan model dan menafsirkan solusi yang diperoleh

4) Mengkomunikasikan gagasan dengan simbol, tabel, diagram, atau media lain untuk memperjelas keadaan atau masalah

5) Memiliki sikap menghargai kegunaan matematika dalam kehidupan,yaitu memiliki rasa ingin tahu, perhatian, dan minat dalam mempelajari matematika, serta sikap ulet dan percaya diri dalam pemecahan masalah

Berdasarkan tujuan pembelajaran matematika di atas, kemampuan penalaran merupakan salah satu kemampuan yang harus dimiliki peserta didik dalam proses pembelajaran matematika. Menurut Ross (dalam Afif, 2016:4) menyatakan bahwa salah satu tujuan terpenting dari pembelajaran matematika adalah mengajarkan kepada peserta didik tentang penalaran. Bila kemampuan bernalar tidak dikembangkan pada peserta didik, maka bagi peserta didik matematika hanya akan menjadi materi yang mengikuti serangkaian prosedur dan meniru contoh-contoh tanpa mengetahui maknanya.

Begitu pentingnya kemampuan penalaran pada pembelajaran matematika sebagaimana dikutip Shadiq (dalam Wardhani, 2008:12) bahwa materi matematika dan penalaran matematis merupakan dua hal yang tidak dapat dipisahkan, yaitu materi matematika dipahami melalui penalaran dan penalaran dilatih melalui belajar matematika. Kemampuan penalaran dapat secara langsung meningkatkan hasil belajar siswa. Tim Puspendik (dalam Afif, 2016:5) menyatakan bahwa peserta didik yang memiliki kemampuan penalaran yang rendah akan kesulitan dalam memahami konsep matematika. Pentingnya kemampuan penalaran matematis juga dikemukakan oleh Suryadi (dalam Afif, 2016:5) yang menyatakan bahwa pembelajaran yang menekankan pada aktivitas penalaran dan pemecahan masalah sangat erat kaitannya dengan pencapaian prestasi siswa yang tinggi.

Menurut Turmudi (dalam Putri, 2014:81) pembelajaran matematika selama ini peserta didik hanya duduk diam sambil mendengarkan penjelasan dari gurunya kemudian mencatat kembali apa yang dicatat oleh guru di depan kelas atau papan tulis selanjutnya mengerjakan soal latihan yang soal dan penyelesaiannya tidak berbeda jauh dengan apa yang dicontohkan oleh guru di depan kelas. Hal ini membuat kelas hanya terjadi interaksi satu arah. Begitu pula dengan pengetahuan yang dimiliki oleh peserta didik hanya terbatas pada apa yang telah diajarkan oleh guru saja. Oleh karena itu, kemampuan bernalar yang seharusnya berkembang dalam diri peserta didik, menjadi tidak berkembang secara optimal.

Megawati (2013) menemukan bahwa kemampuan matematika peserta didik berpengaruh pada kemampuan bernalarnya. Peserta didik yang memiliki kemampuan matematika tinggi cenderung memiliki kemampuan bernalar yang sangat baik. Peserta didik yang memiliki kemampuan matematika sedang cenderung memiliki kemampuan bernalar yang cukup baik, sedangkan peserta didik yang memiliki kemampuan matematika rendah cenderung memiliki kemampuan bernalar yang kurang baik.

Selain beberapa hal di atas, hasil wawancara peneliti kepada tiga peserta 
didik kelas XI MIPA di SMAN 6 Malangmenunjukkan bahwa beberapa peserta didik menyatakan mengalami kesulitan dalam menyelesaikan soal program linier, sehingga sering sekali terjadi kesalahan dalam menyelesaikannya. Kesalahan yang terjadi dalam meyelesaikan soal program linier biasanya disebabkan oleh beberapa faktor antara lain peserta didik kesulitan dalam menerjemahkan soal ke dalam bentuk model matematika, peserta didik kesulitan dalam menentukan titik-titik koordinat, peserta didik keliru dalam membuat grafik, peserta didik bingung dalam menentukan daerah penyelesaian pada grafik, dan peserta didik kesulitan dalam menentukan titik koordinat $x$ dan $y$ yang menjadi titik perpotongan pada grafik. Hal ini menyebabkan hasil belajar kurang maksimal.

Penalaran adalah proses mengambil kesimpulan atau membentuk pendapat berdasarkan fakta-fakta tertentu yang telah tersedia, atau berdasarkan konklusi-konklusi tertentu yang telah dibuktikan kebenarannya (Khalimi, 2011:180). Sejalan dengan pengertian tersebut, Shadiq (dalam Wardhani, 2008:11) mengatakan penalaran merupakan suatu kegiatan, suatu proses atau suatu aktivitas berpikir untuk menarik suatu kesimpulan atau membuat suatu pernyataan baru yang benar berdasar pada beberapa pernyataan yang kebenarannya telah dibuktikan atau diasumsikan sebelumnya.

Bernalar merupakan proses yang dialektis artinya selama kita bernalar atau berpikir, pikiran kita dalam keadaan tanya jawab untuk dapat meletakkan hubungan antara pengetahuanpengetahuan yang kita miliki. Para ahli logika mengemukakan ada tiga proses yang harus dilalui dalam bernalar, yaitu membentuk pengertian, membentuk pendapat, membentuk kesimpulan (Baharudin, 2007:121).

Tidak semua berpikir merupakan penalaran. Sebagaimana dinyatakan oleh (Soekadijo, 2008:6) mengenai terjadinya penalaran. Proses berpikir dimulai dari pengamatan indera atau observasi empirik. Proses itu di dalam pikiran menghasilkan sejumlah pengertian dan proposisi sekaligus. Berdasarkan pengamatan-pengamatan indera yang sejenis, pikiran menyusun proposisi yang sejenis pula. Proses inilah yang disebut dengan penalaran yaitu bahwa berdasarkan sejumlah proposisi yang diketahui atau dianggap benar kemudian digunakan untuk menyimpulkan sebuah proposisi yang baru yang sebelumnya tidak diketahui.

Sebagai suatu kegiatan berpikir maka penalaran mempunyai ciri-ciri tertentu. Adapun ciri-ciri penalaran menurut Suriasumantri (2010:43) adalah sebagai berikut :

1. Adanya suatu pola pikir yang disebut logika. Dalam hal ini dapat dikatakan bahwa kegiatan penalaran merupakan suatu proses berpikir logis. Berpikir logis ini diartikan sebagai berpikir menurut suatu pola tertentu atau menurut logika tertentu.

2. Proses berpikirnya analitik. Penalaran merupakan suatu kegiatan yang mengandalkan diri pada suatu analitik, dalam kerangka berpikir yang dipergunakan untuk analitik tersebut adalah logika penalaran yang bersangkutan.

Mengembangkan kemampuan penalaran tidak lepas dari pemikiran untuk mengamati gejala matematika, membuat dugaan, menguji generalisasi dan memberikan alasan logis dalam pengambilan kesimpulan. Berdasarkan materi dan karakteristik peserta didik pada penelitian ini, indikator kemampuan 
penalaran matematis yang digunakan oleh peneliti adalah:

1. Melakukan manipulasi matematika

2. Kemampuan menyajikan pernyataan matematika secara tertulis, diagram, dan gambar

3. Menyusun dan memberikan alasan terhadap kebenaran solusi

4. Menarik kesimpulan pernyataan secara logis

Soal cerita merupakan permasalahan yang dinyatakan dalam bentuk kalimat bermakna dan mudah dipahami (Wijaya, 2008:14). Rahardjo (2011:8) mengatakan bahwa, soal cerita yang terdapat dalam matematika merupakan persoalan-persoalan yang terkait dengan permasalahanpermasalahan dalam kehidupan seharihari yang dapat dicari penyelesaiannya dengan menggunakan kalimat matematika. Kalimat matematika yang dimaksud dalam penyataan tersebut adalah kalimat matematika yang memuat operasi-operasi hitung bilangan.

Menurut Jonassen (dalam Yudharina, 2015:8) dalam menyelesaikan soal cerita matematika bukan sekedar memperoleh hasil yang berupa jawaban dari hal yang ditanyakan, tetapi yang lebih penting siswa harus mengetahui dan memahami proses berpikir atau langkahlangkah untuk mendapatkan jawaban tersebut. Sebagai contoh dalam menyelesaikan soal cerita diperlukan langkah-langkah tertentu untuk mendapatkan penyelesaian. Kalimat dalam soal cerita perlu dipahami lalu diterjermahkan kedalam bentuk matematika utnuk mendapatkan penyelesaian. Langkah-langkah tersebut yang sangat diperlukan dalam menyelesaikan soal cerita matematika.

Soedjadi (dalam Wijaya: 2010:2) menyatakan bahwa untuk menyelesaikan soal cerita matematika dapat ditempuh langkah-langkah sebagai berikut:
1. Membaca soal cerita dengan cermat untuk menangkap makna pada tiap kalimat

2. Memisahkan dan mengungkapkan apa yang diketahui dalam soal, apa yang ditanyakan oleh soal

3. Membuat model matematika dari soal

4. Menyelesaikan model matematika menurut aturan matematika sehingga mendapat jawaban dari soal tersebut

5. Mengembalikan jawaban kedalam konteks soal yang ditanyakan

\section{Metode Penelitian}

Penelitian ini merupakan penelitian kualitatif-deskriptif dengan tujuan mendeskripsikan kemampuan penalaran peserta didik dalam menyelesaikan soal cerita. Subjek penelitian yaitu peserta didik kelas XI MIPA 4 SMAN 6 Malang berjumlah 6 orang, yaitu S-15, S-5, S-9, S-1, S-2, dan S-13. Penentuan subjek pada penelitian ini adalah secara acak. Kehadiran peneliti pada penelitian ini adalah sebagai instrumen utama, artinya kedudukan peneliti merupakan penentu adalam mereduksi, menganalisis data, dan pembuat kesimpulan.

Prosedur pengumpulan data yang digunakan peneliti dalam penelitian ini adalah sebagai berikut:

1. Tes

Tes ini bertujuan untuk memperoleh data kualitatif mengenai kemampuan penalaran matematis peserta didik dalam menyelesaikan soal cerita. Instrumen yang digunakan adalah soal tes kemampuan penalaran matematis yang dibuat dalam bentuk tes subjektif, berupa soal uraian sebanyak 3 nomor. Materi yang ditekankan dalam tes ini adalah materi program linier dengan soal berbentuk soal cerita.

2. Wawancara

Untuk melengkapi informasi yang berasal dari pemberian tes maka proses 
yang dilakukan selanjutnya adalah wawancara. Metode wawancara yang digunakan adalah wawancara tidak terstruktur. Pedoman wawancara tidak terstruktur berisi garis besar data yang ingin diperoleh.

Analisis data yang digunakan dalam penelitian ini adalah analisis data kualitatif. Analisis data kualitatif terdiri dari tiga alur yaitu, (1) Reduksi data, (2) Penyajian data, dan (3) Penarikan kesimpulan. Pengecekan keabsahan temuan dalam penelitian ini menggunakan triangulasi sumber, dengan jalan: (1) Membandingkan hasil tes kemampuan penalaran matematis dan wawancara; (2) Memaparkan hubungan antara data hasil tes kemampuan penalaran matematis dan hasil wawancara.

\section{Hasil dan Pembahasan}

Dari hasil tes dan wawancara dapat dilihat kemampuan penalaran matematis peserta didik yang dikategorikan dengan predikat rendah, sedang, dan tinggi yaitu sebagai berikut:

1. Kategori rendah

Berdasarkan hasil tes dan wawancara subjek yang memiliki kemampuan penalaran matematis kategori rendah adalah S-15 dengan skor hasil tes yang diperoleh adalah 5. Peserta didik dengan kemampuan penalaran matematis kategori rendah apabila peserta didik dapat melakukan manipulasi matematika dengan benar namun kurang lengkap, dapat menyusun bukti dan memberikan alasan terhadap kebenaran solusi dengan benar namun kurang lengkap, tidak dapat menyajikan pernyataan matematika secara tertulis, diagram, dan gambar, dapat menarik kesimpulan pernyataan secara logis dengan benar dan lengkap.

2. Kategori sedang

Berdasarkan hasil tes dan wawancara subjek yang memiliki kemampuan penalaran matematis kategori sedang adalah S-5 dan S-9. Skor hasil tes S-5 adalah 12 dan S-9 adalah 16. Peserta didik dapat melakukan manipulasi matematika dengan benar namun kurang, dapat menyusun bukti dan memberikan alasan terhadap kebenaran solusi dengan benar namun kurang lengkap, dapat menyajikan pernyataan matematika secara tertulis, diagram, dan gambar dengan benar namun kurang lengkap, dapat menarik kesimpulan pernyataan secara logis dengan benar namun kurang lengkap.

3. Kategori tinggi

Berdasarkan hasil tes dan wawancara subjek yang memiliki kemampuan penalaran matematis kategori tinggi adalah S-1, S-2, dan S-13. Skor hasil tes S-1 adalah 20, S-2 adalah 23, dan S-13 adalah 24. Peserta didik dapat melakukan manipulasi matematika dengan benar dan lengkap, dapat menyusun bukti dan memberikan alasan terhadap kebenaran solusi dengan benar dan lengkap, dapat menyajikan pernyataan matematika secara tertulis, diagram, dan gambar dengan benar dan lengkap, dapat menarik kesimpulan pernyataan secara logis dengan benar dan lengkap.

\section{Kesimpulan}

Berdasarkan hasil penelitian kemampuan penalaran matematis peserta didik di SMAN 6 Malang memiliki tingkat kemampuan penalaran bervariasi yaitu peserta didik dengan kemampuan penalaran matematis kategori rendah sebesar 4\%, peserta didik dengan kemampuan penalaran matematis kategori rendah apabila peserta didik dapat melakukan manipulasi matematika dengan benar namun kurang lengkap, dapat menyusun bukti dan memberikan alasan terhadap kebenaran solusi dengan benar namun kurang lengkap, tidak dapat menyajikan pernyataan matematika 
secara tertulis, diagram, dan gambar, dapat menarik kesimpulan pernyataan secara logis dengan benar dan lengkap. Peserta didik dengan kemampuan penalaran matematis kategori sedang sebesar 32\%, peserta didik dapat melakukan manipulasi matematika dengan benar namun kurang, dapat menyusun bukti dan memberikan alasan terhadap kebenaran solusi dengan benar namun kurang lengkap, dapat menyajikan pernyataan matematika secara tertulis, diagram, dan gambar dengan benar namun kurang lengkap, dapat menarik kesimpulan pernyataan secara logis dengan benar namun kurang lengkap. Peserta didik dengan kemampuan penalaran matematis kategori tinggi sebesar 64\%, peserta didik dapat melakukan manipulasi matematika dengan benar dan lengkap, dapat menyusun bukti dan memberikan alasan terhadap kebenaran solusi dengan benar dan lengkap, dapat menyajikan pernyataan matematika secara tertulis, diagram, dan gambar dengan benar dan lengkap, dapat menarik kesimpulan pernyataan secara logis dengan benar dan lengkap. Secara umum sebagian besar peserta didik kelas XI MIPA 4 SMAN 6 Malang memiliki kemampuan penalarang yang tinggi.

Dari hasil penelitian dan kesimpulan bahwa, bagi guru diharapkan untuk memberikan soal-soal matematika yang bertujuan untuk melatih kemampuan penalaran dan mengurangi penggunaan rumus cepat dalam pembelajaran matematika.

\section{Daftar Rujukan}

Afif, A. 2016. Analisis Kemampuan Penalaran Matematis Ditinjau dari Gaya Belajar Siswa Dalam Problem Based Learning (PBL), (Online),(https://www.academia.ed

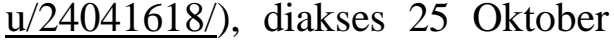
2016.

Baharudin. 2007. Psikologi Pendidikan. Yogyakarta: Ar Ruzz Media

Khalimi. 2011. Logika; Teori dan Aplikasi. Jakarta: Gaung Persada (GP) Press

Maimunah. 2016. Penerapan Model Pembelajaran Matematika Melalui Pemecahan Masalah untuk Meningkatkan Penalaran Matematis Siswa Kelas X-A SMA Al-Muslihun, 1 (1): 17-30, (Online), (http://jrpm.uinsby.ac.id) diakses 11 Januari 2017

Megawati, D. 2013. Profil Penalaran Siswa SMA Al Hikmah Surabaya dalam Membuktikan Identitas Trigonometri Ditinjau dari Kemampuan Matematika,(Online), (http://ejournal.unesa.ac.id/article/1 6441/30), diakses 24 Desember 2016.

Putri, dkk. 2014. Keefektifan Pembelajaran Matematika dengan Pendekatan CTL dan Problem Posing Ditinjau dari Ketercapaian SK/KD dan Kemampuan Koneksi Matematik, 9 (1): 78-89. (Online), (http://journal.uny.ac.id/index.php/ pythagoras), diakses 27 Oktober 2016

Rahardjo, dkk. 2011. Pembelajaran Soal Cerita Operasi Hitung Campuran di Sekolah Dasar (Modul Matematika SD dan SMP Program Bermutu). Yogyakarta: PPPPTK Matematika.

Soekadijo,

$\mathrm{R}$. 2008. Logika Dasar: Tradisional, Simboli $k$, dan Induktif. Jakarta: Gramedia Pustaka Utama

Suriasumantri, J. 2010. Filsafat Ilmu; Sebuah Pengantar Populer. Jakarta: Pustaka Sinar Harapan Wardhani, S. 2008. Analisis SI dan SKL Mata Pelajaran Matematika 
SMP/MTs untuk Optimalisasi Pencapaian Tujuan. Yogyakarta. Pusat Pengembangan Dan Pemberdayaan Pendidik Dan Tenaga Kependidikan Matematika Wijaya. 2007. Pendidikan Remedial. Bandung: Rosdakarya Yudharina, P. 2015. Meningkatkan Kemampuan Menyelesaikan Soal
Cerita Matematika Siswa Kelas V Sd Negeri Mejing 2 Melalui Model Pembelajaran Creative Problem Solving Tahun Ajaran 2014/201, (Online),

(http://eprints.uny.ac.id/19328/), diakses 12 Desember 2016 